\title{
Epithelial Splicing Regulatory Protein 1
}

National Cancer Institute

\section{Source}

National Cancer Institute. Epithelial Splicing Regulatory Protein 1. NCI Thesaurus. Code C101499.

Epithelial splicing regulatory protein 1 ( $681 \mathrm{aa}, \sim 76 \mathrm{kDa}$ ) is encoded by the human ESRP1 gene. This protein is involved in the mediation of mRNA splicing. 